\title{
PERHITUNGAN INTENSITAS GEMPA BUMI BERDASARKAN NILAI PGA (PEAK GROUND ACCELERATION) MENGGUNAKAN DATA GEMPA BUMI MULTI-EVENT (STUDI KASUS: KABUPATEN PANDEGLANG, BANTEN)
}

\author{
Teguh Hariyanto ${ }^{1}$, Filsa Bioresita², Chomia Nilam Safitri ${ }^{3}$ \\ 1,2,3 Departemen Teknik Geomatika, FTSPK-ITS, Kampus ITS Sukolilo, Surabaya, 60111, Indonesia \\ e-mail: ${ }^{1}$ teguh_hr@geodesy.its.ac.id
}

\begin{abstract}
Abstrak
Kabupaten Pandeglang terletak di wilayah pesisir pantai selatan Pulau Jawa yang berdekatan dengan zona subduksi megathrust. Zona ini berasal dari pertemuan Lempeng Indo-Australia yang menunjam di bawah Lempeng Eurasia. Sehingga dapat menyebabkan sering terjadinya gempa bumi akibat pergerakan lempeng yang menunjam di wilayah tersebut. Selain itu, Kabupaten Pandeglang juga berbatasan dengan Selat Sunda di bagian barat di mana wilayah tersebut terdapat Gunung Krakatau yang berpotensi menimbulkan gempa bumi akibat letusan gunung berapi. Untuk itu, perlu adanya analisis perhitungan intensitas gempa bumi di Kabupaten Pandeglang sebagai langkah awal dalam mitigasi bencana. Proses ini menggunakan data gempa bumi multi-event yaitu periode tahun 2010 - 2018 dengan menggunakan metode perhitungan intensitas gempa bumi yang dihitung berdasarkan nilai PGA (Peak Ground Acceleration). Intensitas yang terdapat di Kabupaten Pandeglang adalah V - VII MMI dengan persentase terbesar $(91,463 \%)$ yaitu VI MMI dengan luas $2513,526 \mathrm{~km}^{2}$. Sedangkan persentase terkecil $(0,301 \%)$ yaitu V MMI dengan luas $8,27 \mathrm{~km}^{2}$. Kecamatan di Kabupaten Pandeglang yang memiliki intensitas tertinggi terhadap gempa bumi adalah Kecamatan Angsana, Cibitung, Cimanggu, Pagelaran, Panimbang, Patia, Sindangresmi, Sobang, dan Sukaresmi.
\end{abstract}

Kata kunci : Gempa Bumi, Intensitas, PGA

\begin{abstract}
Pandeglang Regency is located in the southern coast of Java Island which is adjacent to the megathrust subduction zone. This zone originates from the meeting of the Indo-Australian Plate which is subducted under the Eurasian Plate. So that it can cause frequent earthquakes due to the movement of the plunging plates. Other than that, Pandeglang Regency is also bordered by the Sunda Strait in the western part where the region has Mount Krakatau which has the potential to cause earthquakes due to volcanic eruptions. For this reason, an analysis of the calculation of earthquake intensity in Pandeglang Regency is needed as an initial step in disaster mitigation. This process uses multi-event earthquake data in the period of 2010 - 2018 and using the earthquake intensity calculation method which is calculated based on the PGA (Peak Ground Acceleration). The range of earthquake intensity in Pandeglang Regency is V - VII MMI with the largest percentage (91.463\%) is VI MMI with area of 2513,526 km². While the smallest percentage (0.301\%) is V MMI with area of $8.27 \mathrm{~km}^{2}$. Districts in Pandeglang Regency which have the highest intensity of earthquakes are Angsana, Cibitung, Cimanggu, Pagelaran, Panimbang, Patia, Sindangresmi, Sobang, and Sukaresmi Districts.
\end{abstract}

Keywords : Earthquake, Intensity, PGA 


\section{PENDAHULUAN}

Pertemuan Lempeng Indo-Australia yang menunjam di bawah Lempeng Eurasia menghasilkan zona subduksi di sepanjang barat Pulau Sumatra, bagian selatan Pulau Jawa, hingga bagian selatan Nusa Tenggara yang disebut dengan megathrust. Akibatnya, pada jalur tersebut akan sering terjadi gempa tektonik akibat pergerakan lempeng yang menunjam tersebut (Hamzah dkk, 2000). Melalui informasi yang diperoleh dari data geofisika, geodesi, dan kegempaan, zona subduksi (penunjaman/ sesar/ patahan) dapat disebut sebagai zona sumber gempa atau algerismic source zone yang memiliki potensi menimbulkan gempa di waktu mendatang (Tim Pusat Studi Gempa Nasional, 2017).

Kabupaten Pandeglang terletak di wilayah pesisir pantai selatan Pulau Jawa yang berdekatan dengan zona subduksi megathrust. Selain itu, gempa bumi di wilayah Kabupaten Pandeglang juga dapat terjadi akibat letusan gunung api di Selat Sunda yaitu Gunung Krakatau yang memiliki potensi terjadinya gempa bumi dan tsunami (Wahyudin, 2011)

Untuk itu, perlu adanya penelitian mengenai identifikasi intensitas gempa bumi di Kabupaten Pandeglang sebagai langkah awal dalam mitigasi bencana. Proses ini menggunakan data gempa bumi multi-event yaitu periode tahun 2010 - 2018. Metode yang digunakan adalah perhitungan PGA (Peak Ground Acceleration) menggunakan persamaan empiris Youngs, dkk (1997) dan intensitas gempa bumi menggunakan persamaan empiris Wald, dkk (1999).

Penentuan persamaan PGA sebagian besar diturunkan di luar Indonesia karena belum adanya persamaan khusus PGA di Indonesia. Oleh karena itu, studi tentang tingkat risiko gempa bumi di suatu wilayah di Indonesia, masih banyak menggunakan persamaan yang diperoleh di wilayah lain di luar Indonesia dengan asumsi adanya kesamaan kondisi geologi dan tektonik dengan wilayah di Indonesia (Rini, 2015). Selain itu, pemilihan persamaan PGA didasarkan pada perbandingan hasil pengolahan data menggunakan persamaan PGA yang ada dengan data rekaman getaran tanah/akselerograf yang terdapat di Indonesia. Ahazarda (2013) melakukan perbandingan tersebut terhadap 11 persamaan PGA untuk sumber gempa subduksi dengan data rekaman akselerograf wilayah Jawa dan Sumatra. Hasilnya menunjukkan bahwa untuk sumber gempa subduksi, persamaan Youngs, dkk (1997), Atkinson-Boore (2003), dan Zhao, dkk (2006) cocok dengan data akselerograf di wilayah Jawa dan Sumatra.

\section{METODE}

\section{Lokasi Penelitian}

Lokasi yang dijadikan studi kasus pada penelitian ini berada di Kabupaten Pandeglang, Provinsi Banten yang secara geografis terletak pada $6^{\circ} 21^{\prime}-7^{\circ} 10^{\prime} \mathrm{LS}$ dan $104^{\circ} 48^{\prime}-106^{\circ} 11^{\prime}$ BT. Secara administrasi, Kabupaten Pandeglang berbatasan dengan Kabupaten Serang di sebelah utara, Kabupaten Lebak di sebelah timur, Samudra Hindia di sebelah selatan, dan Selat Sunda di sebelah barat.

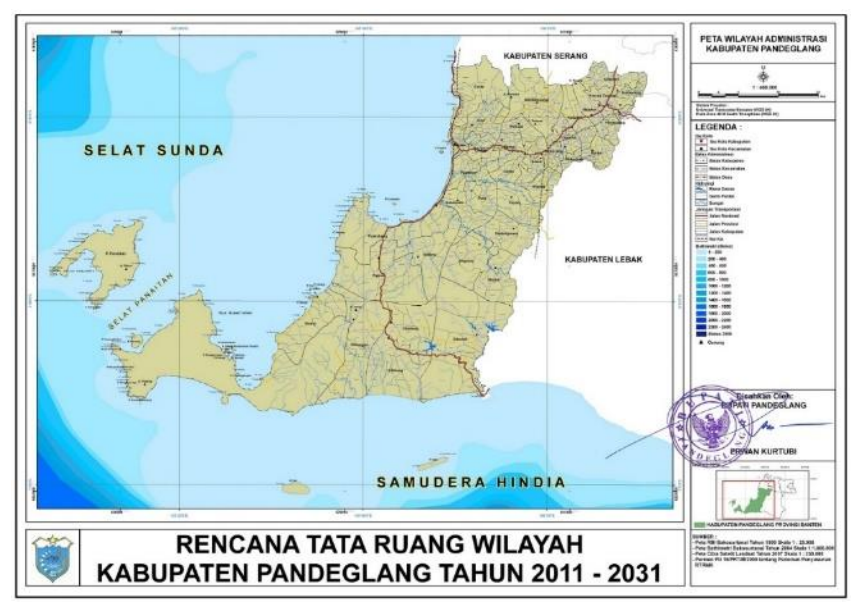

Gambar 1. Peta Administrasi Kabupaten Pandeglang (Pemerintah Daerah Kabupaten Pandeglang, 2016)

\section{Alat}

Peralatan yang digunakan dalam penelitian ini terdiri dari beberapa perangkat lunak, antara lain:

1. Perangkat lunak pengolah data SIG

2. Perangkat lunak pengolah angka

\section{Bahan}

Pada penelitian ini dibutuhkan beberapa data untuk menunjang pelaksanaan penelitian, antara lain:

1. Data Gempa Bumi Kabupaten Pandeglang Tahun 2010-2018

2. Peta Administrasi Kabupaten Pandeglang

3. Peta Geologi Kabupaten Pandeglang

4. Peta Jenis Tanah Kabupaten Pandeglang 


\section{Metodologi Penelitian}

Pelaksanaan penelitian ini terdiri dari beberapa tahapan, antara lain:

1. Tahap Persiapan

Pada tahap ini dilakukan identifikasi terhadap permasalahan yang dapat dijadikan suatu penelitian beserta studi literatur yang berfungsi sebagai referensi dalam melakukan penelitian. Literatur dapat berupa buku maupun jurnal penelitian dengan sumber yang dapat dipertanggungjawabkan.

2. Tahap Pengumpulan Data

Tahap ini diperlukan untuk mendapatkan data yang diperlukan dalam penelitian.

3. Tahap Pengolahan Data

Berikut ini merupakan diagram alir tahap pengolahan data:

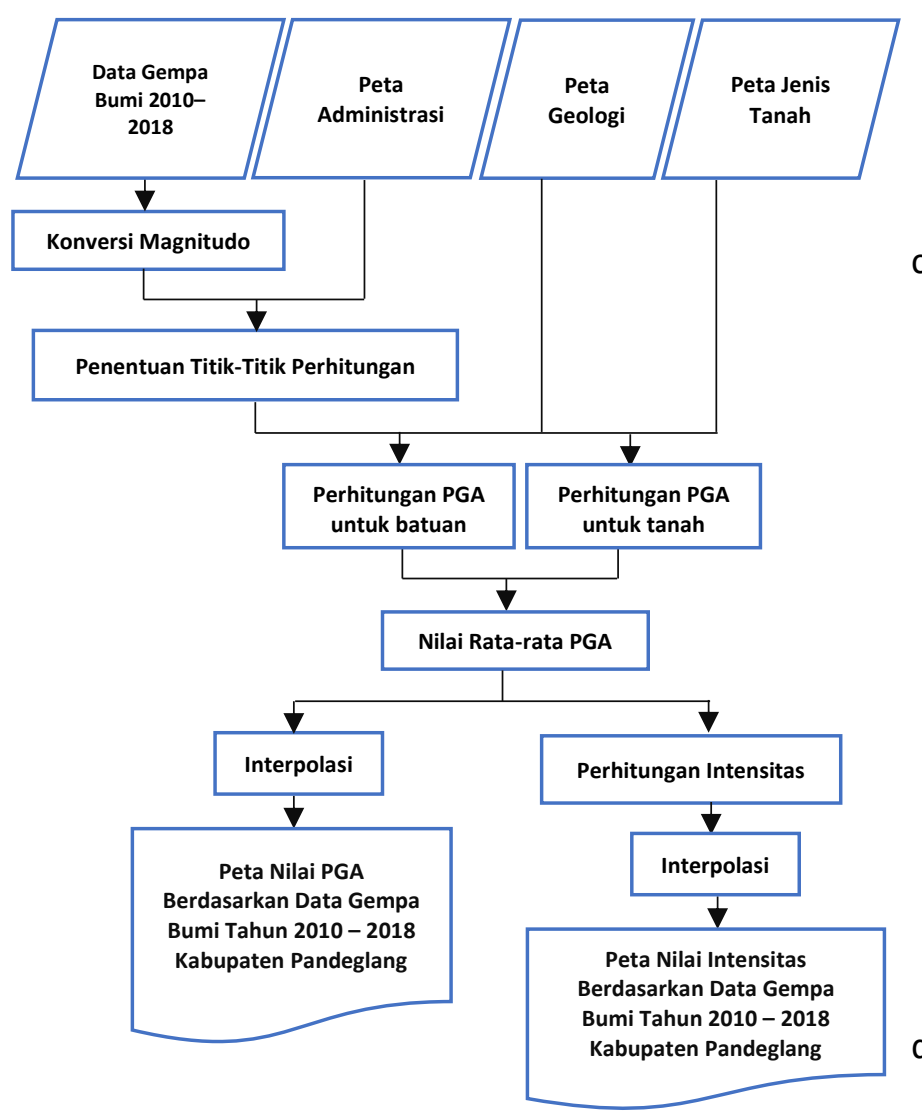

Gambar 2. Diagram Alir Pengolahan Data

Berikut ini merupakan penjelasan diagram alir perhitungan PGA dan intensitas gempa bumi:

a. Data-data yang digunakan adalah Data Gempa Bumi Kabupaten Pandeglang Tahun 2010 2018, Peta Administrasi, Peta Geologi, dan Peta Jenis Tanah Kabupaten Pandeglang. Berikut ini merupakan Data Gempa Bumi Kabupaten Pandeglang Tahun 2010 - 2018 yang di dalamnya terdapat 1024 event gempa bumi.

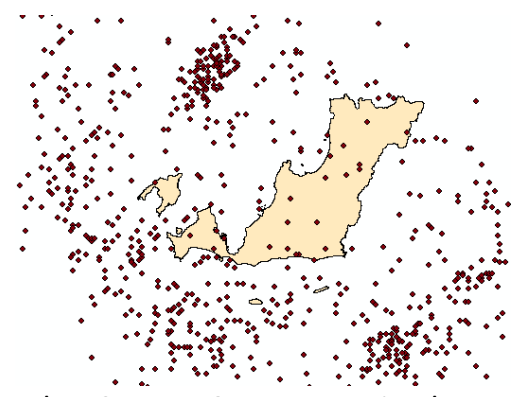

Gambar 3. Data Gempa Bumi Kabupaten

Pandeglang Tahun 2010-2018

b. Konversi semua tipe magnitudo ke dalam bentuk Magnitudo Momen (Mw). Berikut ini merupakan persamaan konversi magnitudo menurut Irsyam, dkk (2010):

$M w=0,114 m b^{2}-0,556 m b+5,560$

$\mathrm{mb}=0,125 \mathrm{ML}^{2}-0,389 \mathrm{ML}-3,513$

dengan:

$\mathrm{Mw}=$ Magnitudo Momen

$\mathrm{mb}=$ body wave magnitude

$\mathrm{ML}=$ Magnitudo Lokal

c. Penentuan titik-titik perhitungan berupa grid yang berukuran $3^{\prime} \times 3^{\prime}$ yang mencakup wilayah Kabupaten Pandeglang secara keseluruhan.

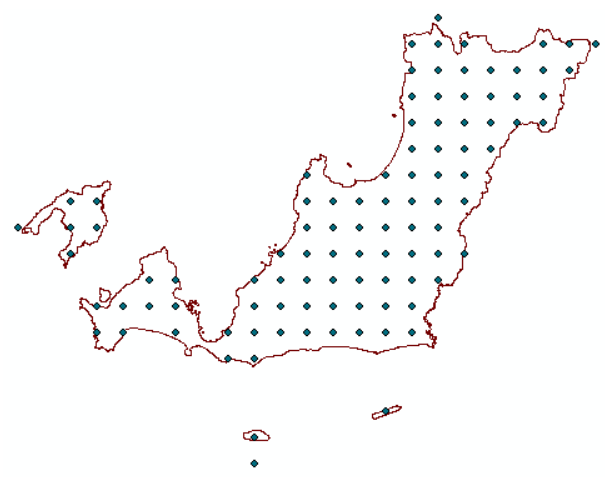

Gambar 4. Titik Grid Wilayah Kabupaten Pandeglang

d. Perhitungan PGA (Peak Ground Acceleration) menggunakan persamaan Youngs, dkk (1997) dengan bentuk persamaan sebagai berikut:

1) Untuk batuan:

$$
\begin{aligned}
\ln (\mathrm{y})= & 0,2418+1,414 \mathrm{M}+\mathrm{C} \ln \left(\mathrm{R}+1,7818 \mathrm{e}^{0,554 \mathrm{M}}\right) \\
& +0,00607 \mathrm{H}+0,3846 \mathrm{Z}_{\mathrm{T}}
\end{aligned}
$$

(3)

2) Untuk tanah:

$$
\begin{aligned}
& \ln (\mathrm{y}) \quad=\quad-0,668 \\
& \ln \left(\mathrm{R}+1,097 \mathrm{e}^{0,617 \mathrm{M}}\right) \\
& +0,00648 \mathrm{H}+0,3643 \mathrm{Z}_{\mathrm{T}}
\end{aligned}
$$


dengan :

$\mathrm{y}=$ nilai peak ground acceleration $(\mathrm{g})$

$\mathrm{C}=-2,552$ (untuk batuan) dan $-2,329$

(untuk tanah)

e $=2,718281828$

$\mathrm{R}=$ jarak hiposenter $(\mathrm{km})$

$\mathrm{M}=$ Magnitudo Momen (Mw)

$\mathrm{Z}_{\mathrm{T}}=$ tipe sumber ( 0 untuk gempa bumi

interface, 1 untuk gempa bumi intraslab)

Perhitungan dilakukan pada 1024 event gempa bumi di tiap titik perhitungan. Setelah itu menentukan nilai PGA terbesar di tiap titik perhitungan untuk digunakan pada proses interpolasi dan perhitungan intensitas gempa bumi. Karena keseluruhan wilayah Kabupaten Pandeglang terdapat batuan dan tanah, maka hasil dari perhitungan PGA menggunakan PGA rata-rata batuan dan tanah.

e. Interpolasi perhitungan PGA menggunakan perangkat lunak pengolah data SIG dengan metode IDW untuk mengubah data titik menjadi poligon sehingga dapat diklasifikasikan sesuai dengan rentang nilai PGA. Hasil berupa "Peta Nilai PGA Berdasarkan Data Gempa Bumi Tahun 20102018 Kabupaten Pandeglang".

f. Perhitungan Intensitas Gempa Bumi menggunakan persamaan Wald, dkk (1999) dengan bentuk persamaan sebagai berikut:

$$
I=3,66 \log \text { PGA - 1,66 }
$$

dengan I adalah intensitas gempa menurut skala MMI.

g. Interpolasi perhitungan Intensitas Gempa Bumi menggunakan perangkat lunak pengolah data SIG dengan metode IDW. Hasil berupa klasifikasi skala I - XII MMI yang disajikan dalam bentuk "Peta Intensitas Berdasarkan Data Gempa Bumi Tahun 2010-2018 Kabupaten Pandeglang".

\section{HASIL DAN PEMBAHASAN}

\section{Hasil Perhitungan PGA dan Intensitas Gempa Bumi}

Berikut ini merupakan hasil dari perhitungan PGA menggunakan persamaan empiris Youngs, dkk (1997) dan intensitas gempa bumi menggunakan persamaan empiris Wald, dkk (1999).
Tabel 1. Hasil Perhitungan PGA dan Intensitas Gempa Bumi

\begin{tabular}{|c|c|c|c|c|c|}
\hline No & $\begin{array}{c}\text { Bujur } \\
\left({ }^{\circ}\right)\end{array}$ & $\begin{array}{c}\text { Lintang } \\
\left({ }^{\circ}\right)\end{array}$ & $\begin{array}{l}\text { PGA } \\
\text { (gal) }\end{array}$ & 1 & $\begin{array}{c}\mathrm{I} \\
(\mathrm{MMI})\end{array}$ \\
\hline 1 & 105,793 & $-6,811$ & 118,691 & 5,932 & VI \\
\hline 2 & 105,843 & $-6,411$ & 154,548 & 6,352 & VI \\
\hline 3 & 105,343 & $-6,711$ & 150,611 & 6,311 & VI \\
\hline 4 & 105,893 & $-6,211$ & 112,385 & 5,846 & VI \\
\hline 5 & 106,043 & $-6,411$ & 85,565 & 5,412 & V \\
\hline 6 & 105,643 & $-6,711$ & 130,905 & 6,088 & VI \\
\hline 7 & 106,193 & $-6,261$ & 81,740 & 5,340 & V \\
\hline 8 & 105,593 & $-6,661$ & 138,025 & 6,172 & VI \\
\hline 9 & 105,093 & $-6,611$ & 131,718 & 6,098 & VI \\
\hline 10 & 105,743 & $-6,761$ & 140,113 & 6,196 & VI \\
\hline 11 & 105,843 & $-6,811$ & 92,991 & 5,544 & V \\
\hline 12 & 105,693 & $-6,561$ & 127,103 & 6,041 & VI \\
\hline 13 & 105,893 & $-6,411$ & 137,100 & 6,162 & VI \\
\hline 14 & 105,593 & $-6,811$ & 147,013 & 6,273 & VI \\
\hline 15 & 105,693 & $-6,761$ & 160,879 & 6,416 & VI \\
\hline 16 & 105,893 & $-6,461$ & 147,451 & 6,277 & VI \\
\hline 17 & 105,543 & $-6,711$ & 108,475 & 5,789 & VI \\
\hline 18 & 105,743 & $-6,611$ & 140,165 & 6,197 & VI \\
\hline 19 & 105,293 & $-6,811$ & 153,266 & 6,339 & VI \\
\hline 20 & 105,993 & $-6,361$ & 111,448 & 5,832 & VI \\
\hline 21 & 105,843 & $-6,461$ & 169,275 & 6,497 & VI \\
\hline 22 & 105,793 & $-6,661$ & 125,139 & 6,016 & VI \\
\hline 23 & 105,943 & $-6,411$ & 110,896 & 5,824 & VI \\
\hline 24 & 105,793 & $-6,711$ & 100,074 & 5,661 & VI \\
\hline 25 & 105,893 & $-6,311$ & 103,417 & 5,713 & VI \\
\hline 26 & 105,243 & $-6,811$ & 167,477 & 6,480 & VI \\
\hline 27 & 105,343 & $-6,761$ & 141,488 & 6,212 & VI \\
\hline 28 & 105,643 & $-6,511$ & 127,880 & 6,051 & VI \\
\hline 29 & 105,843 & $-6,711$ & 97,899 & 5,626 & VI \\
\hline 30 & 106,093 & $-6,261$ & 133,469 & 6,119 & VI \\
\hline 31 & 105,543 & $-7,061$ & 167,070 & 6,476 & VI \\
\hline 32 & 105,743 & $-6,661$ & 115,962 & 5,895 & VI \\
\hline 33 & 105,893 & $-6,261$ & 113,340 & 5,859 & VI \\
\hline 34 & 105,793 & $-6,561$ & 179,980 & 6,594 & VII \\
\hline 35 & 105,593 & $-6,761$ & 137,998 & 6,172 & $\mathrm{VI}$ \\
\hline 36 & 105,843 & $-6,611$ & 152,443 & 6,330 & VI \\
\hline 37 & 105,643 & $-6,761$ & 159,841 & 6,405 & VI \\
\hline 38 & 105,493 & $-6,861$ & 172,698 & 6,528 & VII \\
\hline 39 & 105,893 & $-6,611$ & 132,938 & 6,113 & VI \\
\hline 40 & 106,043 & $-6,311$ & 138,049 & 6,173 & VI \\
\hline 41 & 106,093 & $-6,361$ & 98,330 & 5,633 & VI \\
\hline 42 & 105,943 & $-6,461$ & 116,746 & 5,906 & VI \\
\hline 43 & 105,793 & $-6,511$ & 177,433 & 6,571 & VII \\
\hline 44 & 105,743 & $-6,711$ & 118,691 & 5,932 & VI \\
\hline 45 & 105,243 & $-6,561$ & 151,353 & 6,319 & VI \\
\hline 46 & 106,093 & $-6,311$ & 118,981 & 5,936 & VI \\
\hline 47 & 105,693 & $-6,661$ & 103,621 & 5,717 & VI \\
\hline 48 & 105,843 & $-6,261$ & 101,488 & 5,683 & VI \\
\hline 49 & 105,593 & $-6,711$ & 117,303 & 5,914 & VI \\
\hline 50 & 105,493 & $-6,811$ & 149,695 & 6,301 & VI \\
\hline 51 & 105,943 & $-6,511$ & 117,170 & 5,912 & VI \\
\hline 52 & 105,793 & $-6,961$ & 100,993 & 5,676 & VI \\
\hline 53 & 105,643 & $-6,661$ & 122,649 & 5,985 & VI \\
\hline 54 & 105,743 & $-6,561$ & 157,525 & 6,382 & $\mathrm{VI}$ \\
\hline 55 & 105,643 & $-6,811$ & 173,734 & 6,538 & VII \\
\hline 56 & 105,793 & $-6,761$ & 113,371 & 5,859 & VI \\
\hline 57 & 106,093 & $-6,411$ & 79,036 & 5,286 & V \\
\hline 58 & 105,643 & $-6,611$ & 141,103 & 6,207 & VI \\
\hline 59 & 105,393 & $-6,761$ & 141,103 & 6,207 & $\mathrm{VI}$ \\
\hline 60 & 105,843 & $-6,661$ & 123,251 & 5,992 & VI \\
\hline 61 & 105,193 & $-6,561$ & 138,187 & 6,174 & $\mathrm{VI}$ \\
\hline 62 & 105,193 & $-6,661$ & 135,968 & 6,148 & $\mathrm{VI}$ \\
\hline 63 & 105,693 & $-6,811$ & 175,055 & 6,550 & VII \\
\hline 64 & 105,543 & $-6,761$ & 111,324 & 5,831 & VI \\
\hline
\end{tabular}




\begin{tabular}{rrrrrl}
\hline & & & & & \\
65 & 105,693 & $-6,711$ & 131,511 & 6,095 & $\mathrm{VI}$ \\
66 & 105,943 & $-6,311$ & 126,010 & 6,027 & $\mathrm{VI}$ \\
67 & 105,743 & $-6,811$ & 149,523 & 6,299 & $\mathrm{VI}$ \\
68 & 105,393 & $-6,811$ & 168,197 & 6,486 & $\mathrm{VI}$ \\
69 & 105,993 & $-6,411$ & 87,282 & 5,444 & $\mathrm{~V}$ \\
70 & 106,143 & $-6,261$ & 104,591 & 5,731 & $\mathrm{VI}$ \\
71 & 105,793 & $-6,611$ & 155,779 & 6,365 & $\mathrm{VI}$ \\
72 & 105,943 & $-6,661$ & 95,348 & 5,584 & $\mathrm{VI}$ \\
73 & 105,543 & $-6,811$ & 132,248 & 6,104 & $\mathrm{VI}$ \\
74 & 105,543 & $-7,011$ & 164,782 & 6,454 & $\mathrm{VI}$ \\
75 & 105,843 & $-6,561$ & 174,990 & 6,549 & $\mathrm{VII}$ \\
76 & 105,193 & $-6,611$ & 116,126 & 5,898 & $\mathrm{VI}$ \\
77 & 105,943 & $-6,261$ & 143,068 & 6,229 & $\mathrm{VI}$ \\
78 & 105,243 & $-6,611$ & 131,076 & 6,090 & $\mathrm{VI}$ \\
79 & 106,143 & $-6,311$ & 96,327 & 5,601 & $\mathrm{VI}$ \\
80 & 105,893 & $-6,561$ & 147,787 & 6,281 & $\mathrm{VI}$ \\
81 & 105,843 & $-6,361$ & 124,643 & 6,010 & $\mathrm{VI}$ \\
82 & 105,943 & $-6,361$ & 102,652 & 5,702 & $\mathrm{VI}$ \\
83 & 105,643 & $-6,561$ & 143,535 & 6,234 & $\mathrm{VI}$ \\
84 & 105,393 & $-6,711$ & 156,030 & 6,367 & $\mathrm{VI}$ \\
85 & 105,893 & $-6,361$ & 114,218 & 5,871 & $\mathrm{VI}$ \\
86 & 105,993 & $-6,461$ & 90,517 & 5,502 & $\mathrm{VI}$ \\
87 & 105,893 & $-6,661$ & 111,424 & 5,832 & $\mathrm{VI}$ \\
88 & 105,693 & $-6,611$ & 116,764 & 5,906 & $\mathrm{VI}$ \\
89 & 105,893 & $-6,511$ & 146,319 & 6,265 & $\mathrm{VI}$ \\
90 & 105,843 & $-6,511$ & 172,643 & 6,528 & $\mathrm{VII}$ \\
91 & 105,843 & $-6,311$ & 96,918 & 5,610 & $\mathrm{VI}$ \\
92 & 105,543 & $-6,861$ & 148,003 & 6,283 & $\mathrm{VI}$ \\
93 & 105,843 & $-6,761$ & 89,991 & 5,492 & $\mathrm{~V}$ \\
94 & 105,993 & $-6,311$ & 141,341 & 6,210 & $\mathrm{VI}$ \\
95 & 105,893 & $-6,711$ & 91,200 & 5,514 & $\mathrm{VI}$ \\
96 & 105,243 & $-6,761$ & 155,789 & 6,365 & $\mathrm{VI}$ \\
97 & 105,943 & $-6,561$ & 117,992 & 5,923 & $\mathrm{VI}$ \\
98 & 105,293 & $-6,761$ & 151,563 & 6,321 & $\mathrm{VI}$ \\
99 & 106,043 & $-6,361$ & 109,632 & 5,806 & $\mathrm{VI}$ \\
\hline & & & & & \\
& & & & & \\
70 & &
\end{tabular}

Untuk nilai intensitas gempa bumi dilakukan pembulatan sesuai dengan skala MMI. Hasil dari perhitungan di atas selanjutnya dilakukan interpolasi dengan metode IDW (Inverse Distance Weighted) agar dapat menjadi Peta Nilai PGA dan Peta Intensitas Gempa Bumi Kabupaten Pandeglang.

Pada Tabel 1 di atas dapat diketahui bahwa terdapat hubungan antara nilai PGA dan intensitas gempa bumi yang berbanding lurus. Semakin besar nilai PGA, maka semakin besar pula intensitas gempa bumi, begitupun sebaliknya.

\section{Peta Nilai PGA}

Berikut ini merupakan hasil dari Peta Nilai PGA (Peak Ground Acceleration) yang didapat dari interpolasi titik-titik pada Tabel 1 lalu dilakukan pemotongan sesuai dengan wilayah penelitian. Setelah itu diklasifikasikan menjadi 3 rentang nilai PGA (gal).

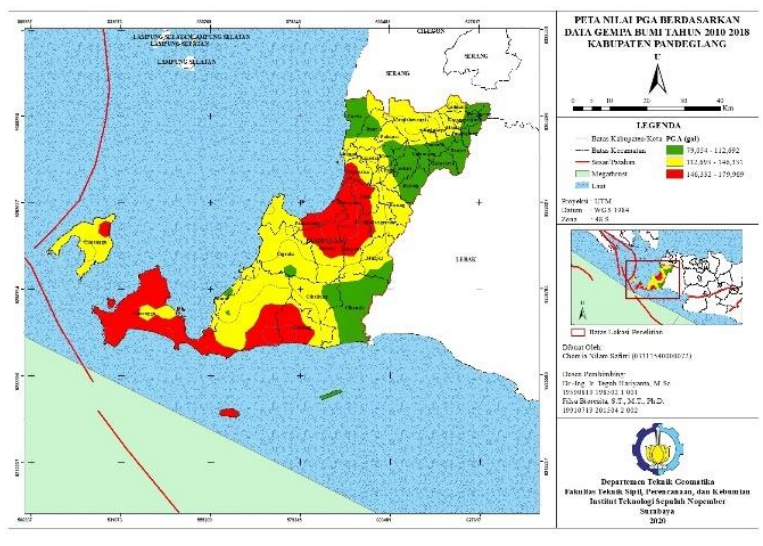

Gambar 6. Peta Nilai PGA

Berdasarkan peta tersebut, dapat diketahui bahwa rentang nilai PGA tertinggi (146,332 - 179,969 gal) terdapat pada Kecamatan Angsana, Cibitung, Cigeulis, Cimanggu, Pagelaran, Panimbang, Patia, Picung, Sindangresmi, Sobang, Sukaresmi, dan Sumur.

Pada Gambar 5 berikut ini disajikan persentase luas rentang nilai PGA yang ada di Kabupaten Pandeglang. Persentase terbesar $(52,246 \%)$ adalah rentang PGA 112,693 - 146,331 gal dengan total luas $1436,249 \mathrm{~km}^{2}$. Sedangkan persentase terkecil $(20,844 \%)$ adalah rentang PGA $79,054-112,692$ gal dengan total luas 572,987 $\mathrm{km}^{2}$.

\section{Persentase Luas Tiap Rentang PGA}

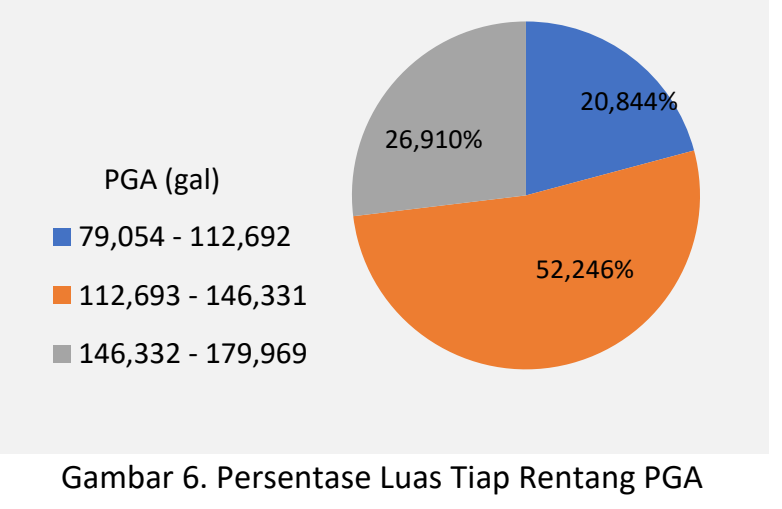

\section{Peta Intensitas Gempa Bumi}

Berikut ini merupakan hasil dari Peta Intensitas Gempa Bumi yang didapat dari interpolasi titik-titik pada Tabel 1 lalu dilakukan pemotongan sesuai dengan wilayah penelitian. Setelah itu diklasifikasikan menjadi 3 nilai intensitas (MMI) yang ada di Kabupaten Pandeglang yaitu V - VII MMI. 


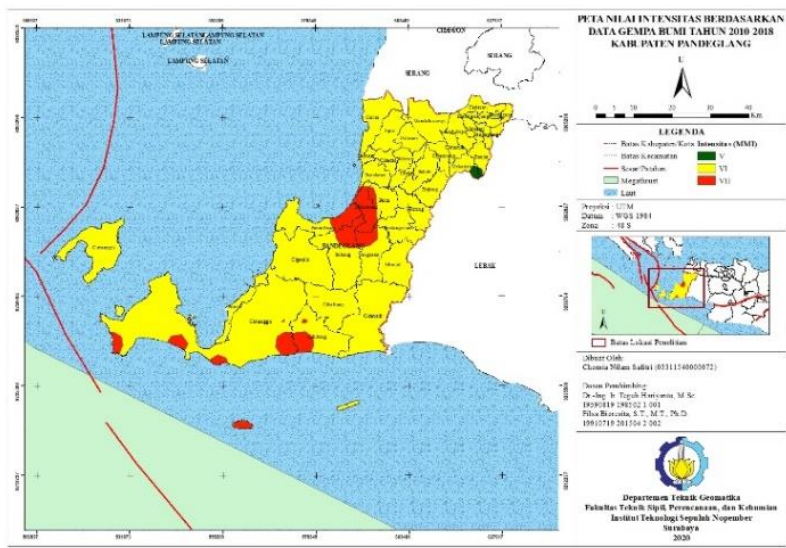

Gambar 7. Peta Intensitas Gempa Bumi

Berdasarkan peta tersebut, dapat diketahui bahwa nilai intensitas tertinggi (VII MMI) terdapat pada Kecamatan Angsana, Cibitung, Cimanggu, Pagelaran, Panimbang, Patia, Sindangresmi, Sobang, dan Sukaresmi.

Persentase luas tiap nilai intensitas digambarkan melalui diagram berikut ini dengan persentase terbesar $(91,463 \%)$ adalah VI MMI dengan luas $2513,526 \mathrm{~km}^{2}$ dan persentase terkecil (0,301\%) adalah $\mathrm{V}$ MMI dengan luas $8,27 \mathrm{~km}^{2}$. Sedangkan untuk VII MMI memiliki persentase $8,236 \%$ dengan luas $226,325 \mathrm{~km}^{2}$.

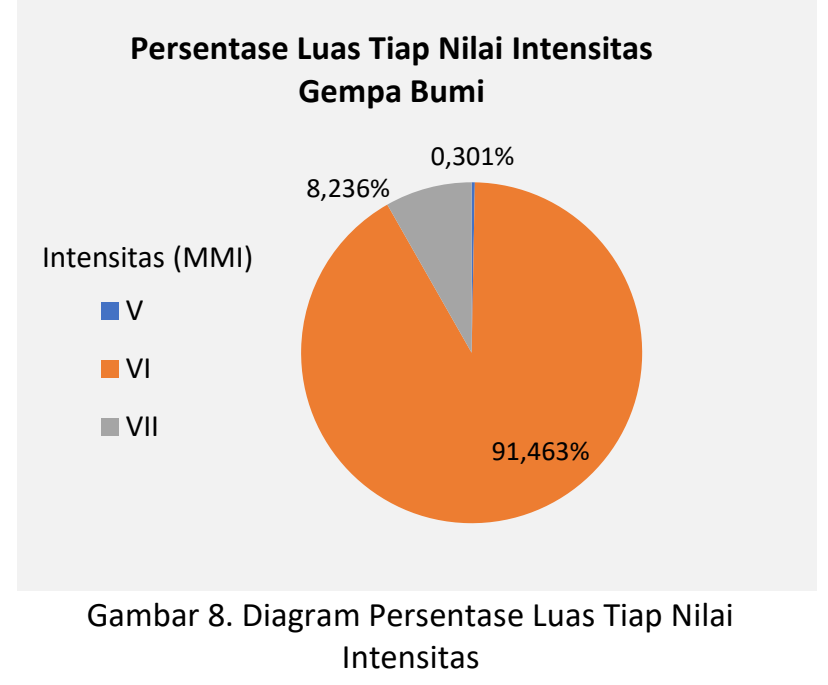

\section{KESIMPULAN}

Berdasarkan hasil dan analisis penelitian ini, maka dapat disimpulkan bahwa:

1. Persentase terbesar luas rentang PGA adalah 52,246\% $\left(1436,249 \mathrm{~km}^{2}\right)$ dengan rentang PGA 112,693 - 146,331 gal. Sedangkan persentase terkecil adalah
$20,844 \%\left(572,987 \mathrm{~km}^{2}\right)$ dengan rentang PGA 79,054 - 112,692 gal.

2. Persentase terbesar nilai intensitas adalah $91,463 \%\left(2513,526 \mathrm{~km}^{2}\right)$ dengan intensitas VI MMI. Sedangkan persentase terkecil adalah $0,301 \% \quad\left(8,27 \quad \mathrm{~km}^{2}\right) \quad$ dengan intensitas $\mathrm{V}$ MMI.

3. Terdapat hubungan antara PGA dan intensitas gempa bumi yang berbanding lurus. Semakin besar nilai PGA, maka semakin besar pula nilai intensitas gempa bumi, begitupun sebaliknya. Hal tersebut ditunjukkan pada Tabel 1 yang merupakan hasil perhitungan PGA dan intensitas gempa bumi. Selain itu, hubungan antara PGA dan intensitas gempa bumi dapat juga ditunjukkan dengan persentase luas. Persentase luas terbesar rentang PGA terdapat pada kategori sedang $(112,693$ 146,331 gal), begitu juga dengan persentase luas terbesar nilai intensitas (VI MMI). Persentase luas terkecil rentang PGA terdapat pada kategori rendah (79,054 - 112,692 gal), begitu juga dengan persentase luas terkecil nilai intensitas (V $\mathrm{MMI}$ ).

4. Kecamatan di Kabupaten Pandeglang yang memiliki intensitas tertinggi terhadap gempa bumi adalah Kecamatan Angsana, Cibitung, Cimanggu, Pagelaran, Panimbang, Patia, Sindangresmi, Sobang, dan Sukaresmi.

\section{UCAPAN TERIMA KASIH}

Penulis mengucapkan terima kasih kepada pihakpihak yang telah membantu dalam pelaksanaan penelitian ini, terutama kepada Badan Meteorologi, Klimatologi dan Geofisika serta Pemerintah Daerah Kabupaten Pandeglang.

\section{DAFTAR PUSTAKA}

Ahazarda, R. 2013. Development of Strong-motion Database for The Sumatra-Java Region. Canberra: The Australian National University.

Atkinson, G. M dan Boore, D. M. 2003. Empirical Groundmotion Relations for Subduction Zone Earthquakes and Their Application to Cascadia and Other Regions. Bulletin of the Seismological Society of America. 93 (4): 17031729. 
Hamzah, dkk. 2000. Tsunami Catalog and Zones in Indonesia. Journal of Natural Disaster Science. 22 (1): 25-43.

Irsyam, dkk. 2010. Ringkasan Hasil Studi Tim Revisi Peta Gempa Indonesia 2010 (Edisi 2). Bandung: Kementerian Pekerjaan Umum.

Pemerintah Daerah Kabupaten Pandeglang. 2016. Rencana Pembangunan Jangka Menengah Daerah (RPJMD) Tahun 2016 - 2021. Tersedia pada

http://bappeda.pandeglangkab.go.id/dokume n-perencaan/. (diakses pada 30 Agustus 2019).

Rini, V. S. 2015. Kajian Awal Persamaan Prediksi Percepatan Tanah di Zona Subduksi Wilayah Bali dan Sekitarnya. Skripsi. Program Sarjana Terapan Geofisika, Sekolah Tinggi Meteorologi Klimatologi dan Geofisika, Tangerang Selatan.

Tim Pusat Studi Gempa Nasional. 2017. Peta Sumber dan Bahaya Gempa Indonesia Tahun 2017.
Bandung: Kementerian Pekerjaan Umum dan Perumahan Rakyat.

Wahyudin, Y. 2011. Karakteristik Sumber Daya Pesisir dan Laut Kawasan Teluk Pelabuhan Ratu, Kabupaten Sukabumi, Jawa Barat. Bonorowo Wetlands. 1(1): 19-32.

Wald, dkk. 1999. Relationship Between Peak Ground Acceleration, Peak Ground Velocity, and Modified Mercalli Intensity in California. Earthquake Spectra. 15 (3): 557-564.

Youngs, dkk. 1997. Strong Ground Motion Attenuation Relationships for Subduction Zone Earthquakes. Seismological Research Letters. 68 (1): 58-73.

Zhao, dkk. 2006. An Empirical Site-classification Method for Strong-motion Stations in Japan using $H / \mathrm{V}$ Response Spectral Ratio. Bulletin of the Seismological Society of America. 96 (3): 914925. 